\title{
Race before Darwin: Variation, adaptation and the natural history of man in post-Enlightenment Edinburgh, 1790-1835
}

\section{Bill Jenkins}

\begin{abstract}
This paper draws on material from the dissertation books of the University of Edinburgh's student societies and surviving lecture notes from the University's professors to shed new light on the debates on human variation, heredity and the origin of races between 1790 and 1835 . That Edinburgh was the most important centre of medical education in the English-speaking world in this period makes this is a particularly significant context. By around 1800 the fixed natural order of the eighteenth century was giving way to a more fluid conception of species and varieties. The dissolution of the 'Great Chain of Being' made interpretations of races as adaptive responses to local climates plausible. The evidence presented show that human variation, inheritance and adaptation were being widely discussed in Edinburgh in the student circles around Charles Darwin when he was a medical student in Edinburgh in the 1820s. It is therefore no surprise to find these same themes recurring in similar form in the evolutionary speculations in his notebooks on the transmutation of species written in the late 1830s during the gestation of his theory of evolution.
\end{abstract}




\section{Introduction}

In Darwin's Sacred Cause Adrian Desmond and James Moore have written of Charles Darwin that '[h]uman evolution wasn't his last piece in the evolution jigsaw; it was the first.'1 If Desmond and Moore are correct that human racial diversity was a preoccupation for Darwin from the very beginning of his evolutionary speculations, a rich mine of ideas on human variation, heredity and race was ready to hand. As this paper will show, the nature and origins of the races had been one of the most hotly debated topics in the circles in which he had moved as a medical student at the University of Edinburgh in 1825-27. These debates therefore have a significance well beyond the lecture theatres and student societies of post-Enlightenment Edinburgh. Desmond and Moore have commented that '[i]t has not been fully appreciated that so many later developments [in physical anthropology] can be traced back to Edinburgh.' ${ }^{2}$ This paper aims to remedy this by shedding new light on the important debate on race that took place at the University of Edinburgh in the decades either side of Darwin's Edinburgh years.

The emergence of a biological interpretation of the physical differences between human populations is often associated with the later decades of the nineteenth century. However, explanations for the origins of human diversity in terms of physiological changes imposed by the conditions of life and the hereditary transmission of these changes has a much longer history. Nicholas Hudson has explored how the category of 'race' came to dominate discourse on the differences between human population in different parts of the globe at the expense of 'nation' and 'tribe' in the course of the eighteenth century. ${ }^{3}$ This development identified by Hudson corresponds closely with the 'shift from lineage-based thinking to a naturalist 
approach' identified by Thierry Hoquet, a process he has described as 'biologization.' ${ }^{4}$ By the end of the century, the idea of race as a set of more or less clearly defined physical characteristics associated with people from a particular region of the world was therefore already well established. As Mark Harrison has shown, this shift had profound implication for colonial policy in India and elsewhere in the course of the nineteenth century. ${ }^{5}$

In contrast to the models proposed by Hudson and Hoquet, Kenan Malik has argued that 'race developed initially as a response to class differences within European society, and was only later applied to differences between Europeans and non-Europeans. ${ }^{6}$ However, the philosophers, natural historians and medical men whose writings I will be discussing here were clearly not transferring pre-existing 'class' distinctions onto the physically diverse inhabitants of distant lands; rather they were seeking to integrate the phenomenon of human 'varieties,' seen as directly equivalent to varieties of animals and plants, into an all-encompassing natural order. This natural order may often have been seen as hierarchical, but it was not simply a transposition of a model of the European social order onto human geographical variation. As Nicolaas Rupke has rightly pointed out, theories of race instead grew out of 'the discovery of a lawlike distribution of life's diversity across the globe. ${ }^{\prime 7}$ Malik's work also raises the important issue of the relationships between science and broader social and cultural currents. As Nancy Stepan has commented 'trying to correlate specific scientific arguments about race with events in the history of racism, nationalism, or imperialism too often results in histories that are vague and do an injustice to the complexities of the scientific issues involved. ${ }^{8}$ With this in mind, I will resist the temptation to correlate the developments I will describe with broader cultural or 
word-historical themes in the absence of clear and unequivocal evidence in contemporary sources to back up such claims.

The professors and students of the University of Edinburgh have left us a particularly rich record of late eighteenth and early nineteenth centuries debates on the nature and origins of the races. In those years the University's medical school was the most important centre for medical education in the English-speaking world. Among its students were many who went on to play important roles in the development of anthropology and natural history later in the nineteenth century. In this paper I will explore how theories of the origin of racial characteristics were received and contested in this particularly significant time and place. I will show how this period saw a retreat from the paradigm of racial groups as products of degeneration from a single primordial race under the influence of inclement conditions, towards a model in which the races were increasingly considered to have moved away from a common origin through adaptation to different climates. This change coincided with the collapse of the 'Great Chain of Being' as the dominant metaphor for the natural order. The main protagonists in my story will be the professors, students and alumni of the University of Edinburgh, and in particular its medical school in the years 1790 to 1835 . Much of the evidence on which I will be basing my argument comes from the records of opinions preserved in the dissertation books of two student societies, the Royal Medical Society of Edinburgh (RMS) and the Royal Physical Society of Edinburgh (RPS), as well as students' notes from the lectures of the University's professors.

Silvia Sebastiani has recently explored attitudes to race among some of the key figures of the Scottish Enlightenment. ${ }^{9}$ In particular, she has examined the opinions of David Hume (1711-76), 
Adam Ferguson (1723-1816), John Millar (1735-1801), William Robertson (1721-93) and Henry

Home, Lord Kames (1696-1782). There are, however, very few references to these historians and philosophers in the sources from Edinburgh medical school circles in the period covered by this study. It is worth pausing for a moment to consider why this might be. It is likely that the medical students and University professors saw race as essentially a scientific question for medical men and natural historians rather than historians and literary scholars. In any case, none of these well-known figures of the Scottish Enlightenment devoted a work entirely to the question of race, and their views generally have to be pieced together from scattered comments in their works on other subjects. With the exception of Kames, it is unlikely that that most of them were seen as authorities on the subject either in their own time or in later decades. It was therefore principally to medical or natural-historical authorities such as Georges-Louis Leclerc, Comte de Buffon (1707-77), Johann Friedrich Blumenbach (1752-1840) and John Hunter (17541809) that the Edinburgh medical men looked for answers to the questions they raised..$^{10}$ The one notable exception to this is Kames, although his ideas were for the most part discussed only in order to refute them.

This debate on race that took place in and around the University of Edinburgh's medical school was extremely significant for the development of ideas on the mutability of varieties and species later in the nineteenth century. Several figures who would become important pioneers in the field of physical anthropology were deeply involved in these speculations. Foremost among these were James Cowles Prichard (1786-1848), author of Researches into the Physical History of Man (1813, and subsequent revised and expanded editions in 1826 and 1837), and 
Robert Knox, author of Races of Men (1850), often considered the founding fathers of physical anthropology in the nineteenth century. ${ }^{11}$ One key figure who left no record of his opinions on race in the Edinburgh sources, but who we can confidently place at the meetings of the RMS and the Plinian Natural History Society, where such theories were widely discussed, was the young Charles Darwin. As we will see, Darwin could hardly have avoided being exposed to these ideas during his two years as a medical student at the University of Edinburgh. The importance of the Edinburgh context for the reception development of pre-Darwinian evolutionary ideas as has been recognized by many eminent historians of science. ${ }^{12} \mathrm{~A}$ better understanding of the questions being asked and answered in Edinburgh regarding the mutability of the human species in this period can only add to our knowledge of this background and shed important light on the development of the ideas that were to radically restructure knowledge of the natural world in subsequent decades.

\section{Species and varieties in late Enlightenment natural history}

By the last decades of the eighteenth century natural history was undergoing a revolution that Nancy Stepan compares to the scientific revolution of the sixteenth and seventeenth centuries in astronomy and natural philosophy..$^{13}$ This revolution set the terms of debate that were to structure the scientific discourse on race well into the nineteenth century. As a consequence, most of the philosophers and natural historians I will be discussing used a fairly consistent set of categories when talking about race. In general, a species was considered to be an essential type of living thing, which was unalterable, at least over human timescales. Even figures who 
doubted the real existence of species, especially when viewed over geological time, largely held to this definition in their discussions of human races. With a few exceptions, most believed that all human beings had a common origin and belonged to the same species. Varieties, on the other hand, were forms of a given species that could be generated over human timescales, either by artificial selection, as in the case of animal breeding, or through the pressures exerted by a given set of conditions of life, including factors such as climate, diet and way of life. As Ludmilla Jordanova has shown, the impact of neo-Hippocratic thought in the eighteenth century with its emphasis on the transformative effects of 'airs, waters and places' on living things lent credence 'theories which stressed organic flexibility and dynamism. ${ }^{14}$ Indeed, such ideas were already well established in the Renaissance period. ${ }^{15}$ According to this principle then, races were generally considered to be varieties of the human species whose physical characteristics had diverged due to their different conditions of life.

Although it was increasingly challenged as the century wore on, the dominant metaphor for the natural order among eighteenth-century natural historians was the 'Great Chain of Being,' still familiar today from Alexander Pope's Essay on Man (1733-34). ${ }^{16}$ This image of the order of nature presented all beings, inanimate as well as animate, as part of a continuous scale linking brute matter with the Deity himself, with man providing a link somewhere in the middle. One important consequence of this scheme was that it placed Homo sapiens squarely within the order of nature, not outside it, and this important principle was to outlive the concept of the Great Chain itself. As John Walker (1731-1803), Edinburgh's professor of natural history, explained to his students: 'This Scale or Chain of Being is composed of all the Bodies in this sublunary 
World, and extends from inert or inanimate Matter gradually up to Man, and there is Reason to believe, that it also extends in a similar Way, from Man to his Maker.'17 Within this rigid structure, no movement was possible from one species to another. It is therefore no surprise that Walker also asserted in his lectures that 'no species of plant or animal is ever changed into another.'18 This was true for species, but the overwhelming evidence provided by the different breeds of domesticated plants and animals proved to Walker that there must be a certain degree of leeway for the appearance of new varieties within a species, defined by him as 'these beings belonging to any species, and differing from it in some trifling circumstance. ${ }^{\prime 19}$

Walker was happy to speculate on the circumstances that could give rise to new varieties. In a set of lecture notes from 1790 he stated that ' $[t]$ he Varieties in the Animal Kingdom proceed no doubt from different Climates.' ${ }^{20}$ In another set of notes from 1797 he provided a second causal mechanism, suggesting that varieties of plants and animals 'generally arise from too sparing, or too luxurious Nourishment.' 21 The Edinburgh encyclopedist William Smellie (1740-95), who had been Walker's rival for the chair of natural history at Edinburgh in 1779, was broadly in agreement. As he wrote in his Philosophy of Nature, 'Varieties or changes in the figure of plants are often produced by soil, by situation, by culture, and by climate. ${ }^{22}$ However, not everyone in late eighteenth-century Edinburgh was so convinced that new varieties of a species were possible. Alexander Monro, secundus (1733-1817), Edinburgh's professor of medicine and surgery, took exception to the suggestion by Buffon that dog breeds all had a common origin. ${ }^{23}$ In his lectures, Monro asserted that 'I think authors in general as Buffon go far wrong in deeming varieties much less constant than they really are for they attribute the many varieties 
of dogs to the difference of climate \& other external causes. ${ }^{24}$ Nonetheless, the opinion that species were mutable enough to produce new varieties, but not new species, seems to have been very widely accepted in the late eighteenth century.

Not everyone, however, was convinced of the fixity of species or the rigidity of the Chain of Being. Buffon questioned the real existence of genera, species and varieties in his monumental Histoire Naturelle (1749-1804), published in an English translation by William Smellie in 1785. In the first volume of the Histoire Naturelle we read that 'In reality only individuals exist in nature, genera, orders and classes only exist in our imagination.'25 Buffon's work was well known and widely cited in Edinburgh during the Enlightenment and after, and must have provided a heady mix of ideas to draw on in their own speculations for young medical students with an interest in natural history.

Most of the figures who wrote on the races of man in this period saw them as directly analogous to varieties of animals and plants, and produced by much the same causes. They often used examples from the animal world to reinforce their arguments regarding humans. For example, in a dissertation written for the RMS by Joseph Reade, an Edinburgh medical student, the analogy is made quite explicit:

Thus, the Blackbird, the Raven and the Bear $\mathrm{w}^{\text {ch }}$ us are black, are gray or white in the North. The union of the same species in the same climate, make it hereditary; I believe the black colour in the Torrid Zone, proceeds from a cause altogether extrinsic, depending solely on local temperature, and in the human species is as accidental as the brown, the red, the yellow, the olive, and the tawny colour. ${ }^{26}$ 


\section{Theories of race in post-Enlightenment Edinburgh}

The subject of the origin of the races was widely discussed in late eighteenth and early nineteenth-century Edinburgh, and it turns up as a frequent subject for dissertations read to Edinburgh's student societies. We know that the question was discussed at the Plinian Natural History Society, whose membership was largely composed of medical students; for example, some 'observations on the influence of Climate in producing varieties in the human species' were made by William A.F. Browne (1805-85) to a meeting of the Society in January 1831, although sadly no further account of what Browne had to say survives..$^{27}$ The survival of the dissertation books of the RMS and RPS mean we know a great deal more about what was actually said at their meetings. According to the rules of the RMS each ordinary member had to provide 'the History of a Case, a Medical or Philosophical Question, and an Aphorism of Hippocrates.' ${ }^{28}$ Although we know less about the Society itself, the dissertation books of the RPS are of a similar nature. In both around two-thirds of surviving dissertations from the period 1790 to 1835 were devoted to strictly medical subjects, while about one third ( 353 for the RMS and 307 for the RPS) were on philosophical subjects, here defined broadly to include questions on human physiology. Of the philosophical dissertations, race was the second most popular subject at the RMS (14 dissertations), with only animal heat being more widely discussed (17 dissertations), while at the RPS it was the third most popular subject (11 dissertations), after the circulation of the blood (15 dissertations) and digestion (13 dissertations). Only one individual wrote essays on race for both societies, Nicholas C. Pitta (d. 1857), whose two dissertations were 
almost identical in content. ${ }^{29}$ He later went on to enlarge on the subject in a book, Treatise on the Influence of Climate on the Human Species (1812), by which time he had established himself as a physician in Madeira. ${ }^{30}$

The five race theorists cited most frequently in Edinburgh sources are Petrus Camper (1722-89), Samuel Stanhope Smith (1751-1819), Buffon, Hunter and Blumenbach. Of the 14 members of the RMS who wrote dissertations on race between 1790 and 1835, 11 supported the hypothesis that, contrary to the opinions of Lord Kames, all the races had a common origin, while only three supported Kames' assertion that they had separate origins. It is notable that all those writing after 1800 supported a common origin of the races, suggesting that a near consensus on this view was established over time. The surviving records of the RPS are less complete, but we know that between 1798 and 1827 eleven members of the RPS also wrote on the same subject. Nine of them supported the common origin of the races, while only one opposed it. One further essay came to no firm conclusions on the subject. The preponderance of monogenist contributions strongly suggests that Kames had relatively few supporters in Edinburgh by the last decade of the eighteenth century and that these became even fewer with the passing years. The last dissenting voice to be found in the records of either Society is from the RPS dissertation book for 1804-6. In his dissertation John Taylor wrote in support of Kames that 'we infer, that from the great difference of some nations from others, in colour, stature, form, and dispositions; peculiarities, which climate may in some measure produce; but not to such extent as we daily observe them; all mankind are not descended from the same family. ${ }^{31}$ However, his lone voice 
only goes to underline the near unanimity of the monogenist position at Edinburgh University by the early years of the nineteenth century.

Interpretations of race based on the account of the early history of humanity given in the book of Genesis were taken seriously in some circles well into the nineteenth century and beyond, as ably chronicled by Colin Kidd and David N. Livingstone. ${ }^{32}$ However, the Edinburgh dissertations rarely alluded to Scripture. When they did, it was usually to deny its relevance to the debate rather than to use it as evidence to bolster their arguments. William Webb, for example, writing for the RMS in around 1794, mentioned the Biblical account only briefly at the very end of his dissertation to support the argument he had already made based on natural causes. He wrote that 'I may, finally, mention that the tradition of Moses, regarded as an historical record, may be considered as affording as much support to the doctrine of a Unity of Species, as can be derived from the testimony of remote antiquity. ${ }^{33}$ Edward Holme, who also gave his dissertation to the RMS in the mid-1790s, was positively dismissive of the evidence of Scripture, writing that 'It would be abusing the patience, and misapplying the time of the society, were I to entire into the Biblical dispute, concerning the original production of Mankind.'34 The vast majority of other members of the two Societies who wrote on the subject neglected to mention Scripture altogether.

Hudson credits Buffon as the first to systematically use the term 'race' to denominate varieties of the human species. ${ }^{35}$ Buffon made it clear in the third volume of his Histoire Naturelle that he considered the races to be varieties of the same species which had varied according to their different conditions of life. There he wrote that 'there was originally only a single species of 
man, which having multiplied and spread over the whole surface of the earth, has undergone different changes through the influence of climate, by differences of nutrition, by those of their way of life, by epidemic diseases and also by the infinitely varied mixture of individuals more or less resembling one another. ${ }^{36}$ Buffon did not believe that such changes could happen in a single lifetime, but rather that 'several centuries and a the succession of a great number of generations are necessary for a white race to develop a tinge of brown and finally become altogether black.' ${ }^{37}$ Camper, Hunter, Smith and Blumenbach all concurred with Buffon that differences in climate and the conditions of life were at the root of racial differences. Different factors could either reinforce or oppose each other; as Smith put it: 'the effect of climate is augmented by a savage state of society and corrected by a state of civilization.'38 In order for these factors to give rise to races it was necessary that, once established, racial characteristics could be transmitted to children by regular laws of inheritance. As Hunter put it: 'either our explanations are idle and futile, or many properties which have been acquired by the parent are transferred to the offspring.' ${ }^{39}$ Over many generations racial characteristics thus became augmented and fixed in the population. ${ }^{40}$

There is no indication that the changes brought about by climate, habits and nutrition were in any sense adaptive for Buffon, Camper or Blumenbach. Buffon and Blumenbach, both of whom had a profound influence on the new science of race in the eighteenth century, saw racial differences primarily as the result of degeneration from an original state. ${ }^{41}$ When discussing the races in the fourteenth volume of his Histoire Naturelle Buffon wrote about the 'generations already degenerated by the influence of different lands. ${ }^{\prime 2}$ Blumenbach was in no doubt that the 
'Caucasian' form was 'the primeval one' from which all other races had diverged under the influence of different climates and ways of life. ${ }^{43} \mathrm{He}$ answered the question 'whether the origin of this diversity can be traced to degeneration' resolutely in the affirmative. ${ }^{44}$ Despite his use of the language of 'degeneration,' Thomas Junker has argued convincingly that Blumenbach, despite his designation of the Caucasian as the original and most beautiful form, did not necessarily intend this to reflect a racial hierarchy of worth. ${ }^{45}$ Camper, on the other hand, does not use the concept of degeneration to discuss the origin of racial difference, but neither does he suggest that racial differences are adaptive. ${ }^{46} \mathrm{He}$ rather seems to have considered them as simple effects of the climate on the body. As we will see in the following section, Hunter and Smith diverged from the 'degeneration' model of racial differentiation in suggesting that racial differences could sometimes be adaptive.

All students espousing the monogenist position agreed with Buffon that climate and way of life were responsible for producing the physical differences between races. In his essay for the RMS in around 1791, John Bradley was typical in writing that: 'The causes, but which we hope, in some degree, to account for the most striking differences of men, are principally Climate and the State of Society; which, by having operated for a length of time, almost infinite perhaps, may alone have brought about the changes which at present appear of so difficult explanation. ${ }^{4} 7$ More than twenty years later, W.F. Neville expressed much the same views in his dissertation for the RPS in around 1815: 'experience and common sense will justify us in coinciding with Buffon and others, that the two principal causes are the effects of Climate and the state of Society.' ${ }^{48}$ 
James Cowles Prichard, who wrote a dissertation for the RMS in 1807 or 1808, was unusual in that, while he believed that 'these natural varieties are considerably modified by the effects of climate \& national manners,' he firmly stated that 'that the influence of these causes is confined to the generation on which they have acted, and that characters thus acquired are not in any instance transmitted to the offspring. ${ }^{49}$ However, it was generally agreed by most students that the characteristics acquired would be heritable, otherwise any changes effected in one generation would be lost in the next. It was this 'hereditary disposition' that allowed the effects of the climate to be transmitted from one generation to another and ultimately become established in a population. While these ideas may call to mind theory of the inheritance of acquired characteristics associated with Jean-Baptiste Lamarck (1744-1829), many of the dissertations discussing this principle predate Lamarck's published work on the subject by some years. Edward Holme, in his dissertation for the RMS in around 1793, defined this hereditary disposition as: 'the cause of the occurrence of appearance in children; in consequence of certain changes produced in their parents, or more remote ancestors, without a reapplication of the exciting cause. ${ }^{\prime 50}$ But it is important to note that these changes could be transmitted only when they altered the fundamental constitution of the body. This precluded the transmission of acquired characteristics based on chance injuries or other one-off accidents. John Fitzgerald wrote in his dissertation for the RMS in around 1798 that: 'It is obvious enough that only constitutional defects or peculiarities are conveyed by birth, and since a burnt face or fractured limb are only particular accidents which have no effect on the inward Constitution, they, therefore, cannot be transmitted to posterity.' ${ }^{51}$ This was generally the conclusion reached by others who considered the question. 
All agreed that the causes of human variation acted extremely slowly over many generations. William Webb wrote that the change 'does not become apparent until after several successive generations have been exposed to the operation of the external agent which produce it, and in such a case it becomes ingrafted, as it were, in the constitution of the race. ${ }^{52}$ Writing around 1803, an RMS member named William Scully concurred that the 'minutest causes acting constantly and long continued will necessarily create great and conspicuous differences among Mankind.'53 The change occurred slowly over many generations and, once fully effected, could not be easily undone by a subsequent change of conditions of life. Dissertation writers in the 1790s and early 1800s often followed Blumenbach and Buffon in viewing racial differences as the result of a degeneration induced by unfavourable conditions. Samuel Cramer, for example, wrote in his dissertation for the RPS in around 1800 that 'all these changes which the African, the Asiatic, or the American undergo are but accidental deformities, which a kinder climate, better nourishment, or more civilized manners would in course of time very probably remove. ${ }^{54}$ What determined the relative places of the races on the scale was primarily which one had retained the more perfect, original form and which had 'degenerated.' In almost all cases white Europeans were regarded as representing the original form of the human species from which all other races had fallen away.

We know from surviving sets of notes taken by students in the early decades of the nineteenth century that both Robert Jameson (1774-1854), Walker's successor as professor of natural history and the University of Edinburgh, and Dugald Stewart (1753-1828), professor of moral philosophy, included material on the origin of the races in their lectures. Figure 1 show a 
diagram from a set of lecture notes taken by one of Jameson's students. ${ }^{55}$ These do not bear a date, but from the watermark on the paper it can reasonably be assumed that they are from the mid-1810s. They show that Jameson taught a monogenist theory of race that very closely followed Blumenbach's scheme of the descent of the different races from a common origin..$^{56}$ The human family is represented as having two branches, both depicting degeneration from the 'Caucasian,' assumed to be the original race of man, to the 'American' via the 'Mongol' and one side and the 'Negro' via the 'Malay' on the other. The same scheme is depicted in an almost identical diagram from a set of notes taken in 1822 by George Gordon (1801-93), a Church of Scotland minister and naturalist, although here Jameson appears to have further subdivided the five principal races into 19 sub-races..$^{57}$

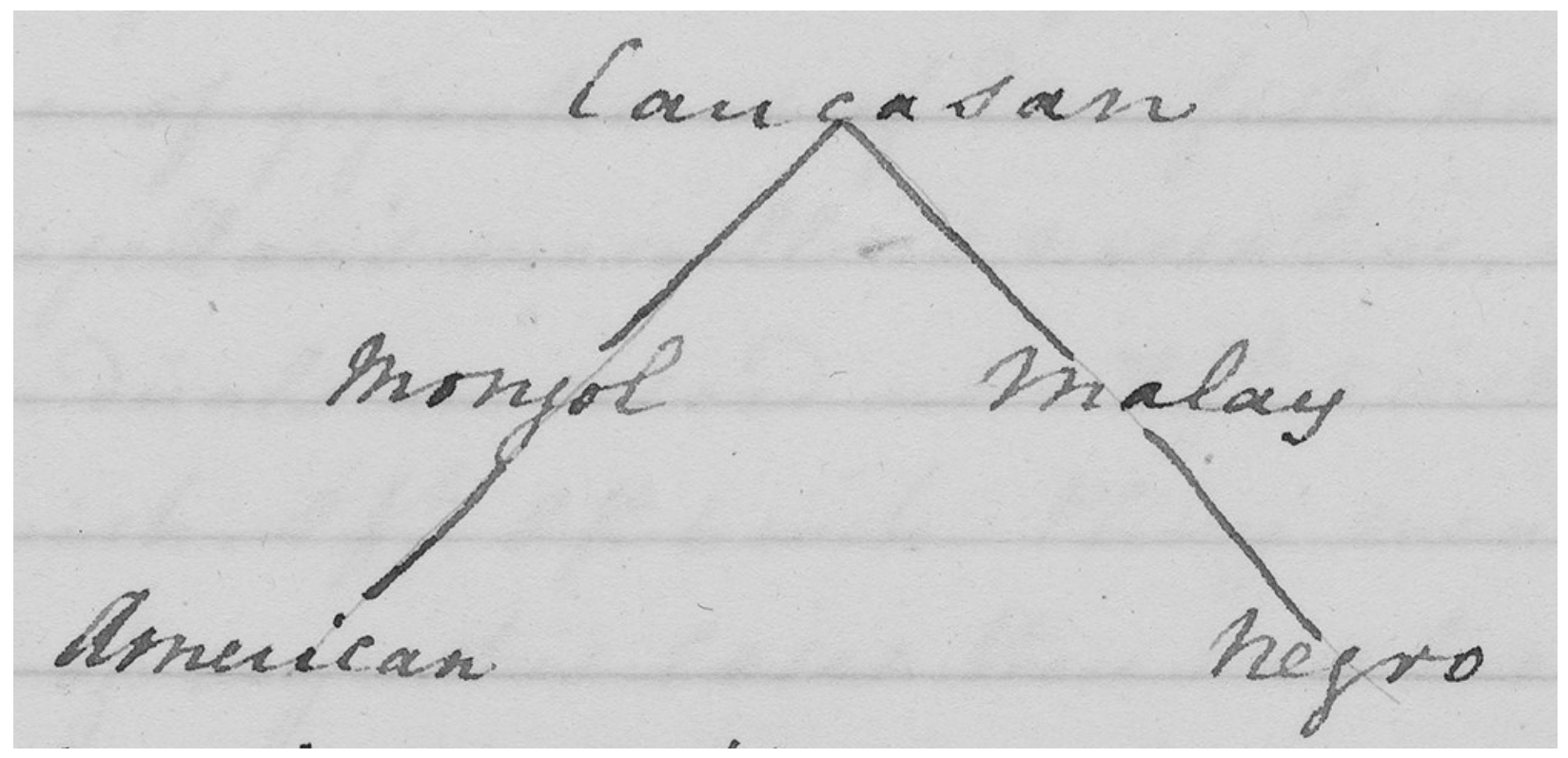

Figure 1. Diagram showing the relationships between the races of man, from an undated set of student notes taken in one of Robert Jameson's natural-history lectures by an anonymous student, Edinburgh University Library, CC-BY. 
Like Jameson, Stewart too clearly followed the opinions of Buffon and Blumenbach that the races all had a common origin and that any physical differences were the consequence of living in different climates. He cited the example, also used by Camper, of the different skin colours of Jewish communities living in different climates as evidence in favour of this view:

the Jews whose strict laws prevented them from intermarrying with any other people since their dispersion into the different quarters of the globe have acquired the colour of the country to which they have resorted. [...] After which we can have no difficulty in conceiving in the course of a number of generations the heat \& brilliancy of the climate may have superinduced the blackness of the Negroes. ${ }^{58}$

From the surviving lecture notes, it is clear that the dominant opinions of the students as expressed in the Societies' dissertation books broadly reflected those of their professors at the University of Edinburgh in the early decades of the nineteenth century.

Outside the University, at least one important teacher at Edinburgh's extra-mural anatomy schools had a strong interest in the question of race. Robert Knox was working as a lecturer at the anatomy school owned by John Barclay by 1824, and would become its proprietor on Barclay's death in 1826. He had himself studied medicine at the University of Edinburgh between 1810 and 1814. His already keen interest in the question of race had been further stimulated by his experiences as a military surgeon in the Cape Colony between 1817 and 1820, when he had the opportunity to observe the Xhosa, Zulu and Khoisan peoples of southern Africa at close quarters, as well as the Boers and English. ${ }^{59}$ Recollections of Knox's experiences at the Cape formed the basis of a paper on race that appeared in in the Memoirs of the Wernerian 
Society in $1824 .{ }^{60}$ In this, Knox espoused the familiar views of Buffon, Blumenbach and Camper that the races are a consequence of the different conditions of life of different peoples:

We may view the human race as derived originally from one stock, to which the arbitrary name of Caucasian has been given. This species, influenced by climate and civilization, assumed, at a very early period, five distinct forms, which have also been arbitrarily designated by the names Caucasian, Mongolic, Ethiopian, American, and Malay. ${ }^{61}$

As Evelleen Richards has shown, Knox was to develop a very different theory of race in later decades. ${ }^{62}$ However, these ideas were not published until the 1850s, and so are beyond the scope of this paper.

Despite the recurrent theme of racial degeneration and the explicit or implicit racial hierarchies represented in their work, the monogenists among Edinburgh's race theorists generally showed themselves to be opponents of slavery and colonial oppression when they chose to draw morals from their theories. Despite racial differences, all people were after all one family and could be raised up the hierarchy over time by exposure to more favourable climates and more 'civilized' ways of life. In the early 1790s John Bradley was typical in stating in his RMS dissertation that his opposition to Kames' polygenism were partly based on their consonance with 'the inhuman cruelty, with which one part of our species, at present, tyrannizes over the other; but which no other supposition can ever reconcile to the laws, either of nature or humanity.' ${ }^{63}$ 


\section{Variation and adaptation}

The idea that physical changes induced by conditions of life could be adaptive was far from being accepted in Edinburgh in the last decade of the eighteenth century. The adaptive nature of racial characteristics could even be rejected as a feature of the polygenist concept of race, in which divine providence had fitted each race to its respective climate from the beginning. John Fitzgerald wrote in his dissertation that ' $[\mathrm{t}] \mathrm{he}$ advocates for many races assert that this is a wise institution of providence to give the inhabitants of each region a particular hue in order that they might be better fitted to the climate, and bear its influence with less inconvenience. ${ }^{64}$ In order to uphold his own monogenist views, Fitzgerald was obliged to argue on the contrary that, rather than being an adaptation, 'a black body when exposed to the sun, absorbs its rays faster, and in greater quantity than the same kind of body of any other colour, hence we might infer that for defence against the intemperate heat of Tropical regions, black of all hues whatever, would be the worst that could be given.' ${ }^{65}$ However, by the early years of the nineteenth century we find suggestions in the Society dissertations books that some students did see racial differences as adaptive. John Taylor, writing in around 1806, suggested that some the different races could be seen as the work of divine providence, which 'has given to man such a nature, as to enable him to accommodate himself to the various parts of the Earth.'66

In the last decades of the eighteenth century the ideas of a 'Great Chain of Being' was under serious challenge, and with it the image of a rigid natural order in which any change represented movement up or down the scale of nature. Some key figures, including Blumenbach, Hunter, and probably also Camper, had already explicitly rejected it. ${ }^{67}$ By the 
early decades of the nineteenth century the Chain of Being was no longer taken seriously by most leading natural historians and it was possible for Robert Jameson to announce in his lectures for 1816/17: 'There is in truth no such regular gradation; and there are wanting many links to connect the whole. It is obvious to all, that if once the chain be broken, this amusing system is overthrown.' ${ }^{68}$ As a consequence it was now becoming possible to see new varieties of species produced by different conditions as having become adapted to a given climate rather than as having slipped down the scale of being due to the deleterious effects of unfavourable conditions or ways of life.

This idea that racial characteristics are adaptive can in fact be traced back to the work of a number of writers in the last few decades of the eighteenth century. John Hunter was an early advocate of the idea that changes in the human body brought about over many generations by the conditions of life represented adaptation to that climate and mode of life rather than a degeneration from a more perfect form. As he wrote in his 'Inaugural disputation on the varieties of man' in 1775, 'who may say that it is not more agreeable to perfect wisdom to have given to different animals that kind of nature, but which they could easily accommodate themselves to whatever might happen, than to have created a fresh species adapted to each change of external circumstances?' ${ }^{69}$ A decade or so later in America Stanhope Smith was advocating a similar view that the appearance of different races was an adaptive response to the different climates in which peoples found themselves. He used this idea to counter the arguments of the polygenists that different races were created for different climates: 'If the advocates of different human species suppose that the beneficent Deity hath created the 
inhabitants of the earth of different colours, because these colours are best adapted to their respective zones; it surely places his benevolence in a more advantageous light to say, he has given to human nature the power of accommodating itself to every zone. ${ }^{\prime 70}$

Although he was not writing about human races, but rather varieties of animals, the Edinburgh geologist James Hutton (1726-97) also speculated about the role of the conditions of life in bringing about adaptive change in an unpublished treatise on agriculture written a few years before his death. Unlike Hunter and Smith, he did not consider adaptive change as the product of a mechanism for producing opportune variations built into living things by a benevolent deity, but rather as the result of differential mortality among different varieties of a species. Because they remained unpublished, however, these speculations probably had little or no impact at the time. Firstly, Hutton proposed that undirected variation was normal in living things, and that there existed, 'a general law or rule of seminal variation, by which the forms of the animal should constantly be changing, more or less, by the influence of external causes, but not with any particular attention. ${ }^{171}$ Using the example of the dog, he went on to suggest that those forms best fitted for their conditions of life would survive and reproduce, while those that were less well adapted would become extinct: 'Thus, for example where dogs are to live by the swiftness of their feet and the sharpness of their sight, the form best adapted to that end will be the most certain of remaining, while those forms that are least adapted to this manner of chace [sic] will be the first to perish[..] $]^{\prime 72}$ By this process new varieties of animals and plants would arise that were better adapted to their surroundings. 
James Cowles Prichard further developed the ideas he had first presented in his RMS dissertation cited above in his famous Researches into the Physical History of Man, published only a few years later in 1813. In the second edition of this book, published in 1826, Prichard proposed that species produced new varieties according to a zoological law; but this process did not represent adaptive change driven by the conditions of life. Neither was it 'merely an accidental phenomenon, but a part of the provision of nature for furnishing to each region an appropriate stock of inhabitants, or for modifying the structure and constitution of species, in such a way as to produce races fitted for each mode and condition of existence. ${ }^{73}$ Once a new race had appeared that was better adapted to its conditions of life, it would come to dominate and selective forces would drive other forms to extinction. As Prichard wrote:

A question now presents itself; how these varieties are developed and preserved in connexion with particular climates and differences of local situation?

One cause which tends to maintain this relation is obvious. Individuals and families, and even whole colonies, perish and disappear in climates for which they are, by peculiarity of constitution, not adapted..$^{74}$

Prichard, a deeply religious man, was profoundly opposed to Erasmus Darwin's theories of the transmutation of species. It was this that led him to reject the idea that climate could directly influence the development of heritable racial characteristics. ${ }^{75}$ Instead, he proposed that the differential survival of varieties more or less suited to their conditions of life acted on an independent cause of variation. 
We see much the same theory again put forward to explain the origins of the races several decades later in the 1830s. E.J. Scott wrote in his dissertation for the RMS in 1833 that, while changes produced in individuals by their conditions of life were not passed from generation to generation, 'the causes of the different varieties of the human species, may be attributed to a mixture in the breed, the primitive difference of which was originally produced by an accidental congenital variety springing up and continuing its influence on a race by hereditary conformation. ${ }^{76}$ The conditions of life would then exert selective pressures on individuals favouring those best adapted to the conditions: 'And as it appears that certain individuals do not flourish in particular climates, so it is most probably that those varieties which have been produced in climates not congenial to them, have been blighted at the commencement and thus races are only constituted and adapted for their respective habitations.' ${ }^{77}$

Scott was not alone in thinking along these lines in the early 1830s. Henry H. Cheek (1807-33), another medical student who wrote a dissertation for the RMS in 1830, also expressed very similar views. In his dissertation he wrote that 'the indigenous races are adapted to the climates in which they are found - and that, if a race be removed to a new region it will either become adapted to the new functions required, by the powers of organization, or that it will propagate a sickly \& imbecile offspring, and ultimately perish. ${ }^{78}$ Unlike Scott, Cheek seems to have believed that variation was directed by 'an ultimate Zoological law, that structures have a tendency to change for adaption to new functions. ${ }^{\prime 79}$ His theory is therefore more akin to those of Hunter and Smith than Hutton. Where Cheek differed from Hutton, as from most of his 
contemporaries, was that he did not recognize the difference between species and varieties. In his RMS dissertation he wrote:

Wherein then does the variety differ from the species, since its characters are often transmitted, merely in the origin of the difference. Thus according to the standard of our knowledge of natural causes, we determine the grade which an object is to hold. If we fancy we can devise a probable cause for a particular diversity, we name it a variety. If mystery overpowers our subtlety, we name it species..$^{80}$

Cheek therefore cast doubt on the reality of the distinction between mutable varieties and immutable species, thereby making the transmutation of one species into another a real possibility.

\section{Conclusion}

It is evident that the ferment of ideas on race in and around the medical school of the University of Edinburgh provided a clearing house for some of the ideas that were to revolutionize understandings of the nature and origins of species in the second half of the century. It is therefore hardly surprising to note that some of the key thinkers that were to emerge in those later decades had been students at Edinburgh during those years. Two figures often seen as founding fathers of physical anthropology, Prichard and Knox, had studied medicine in Edinburgh. Other notable Edinburgh graduates from this period who were to make important 
contributions to the science of life in latter decades included William Benjamin Carpenter (181355), Hewett Cottrell Watson (1804-81) and, of course, Charles Darwin himself.

The debates chronicled here on variation, heredity and the mutability of the races were in full flow in student circles in Edinburgh at just the time that Darwin was studying medicine at the city's University. It is therefore hardly surprising that the different theories of the origins of variation, and the question of whether or not it was random or directed by some 'zoological law, find echoes the speculations found in Darwin's notebooks in 1837-38 as he wrestled with the problem of the source of the variations on which, as Dov Ospovat has shown, his whole theory of evolution was to be founded.$^{81}$ Phillip R. Sloan has also written in some detail about the 'ever-present biological concerns that can be followed in Darwin's thought in an unbroken line from his earliest Edinburgh days through the Cambridge and Beagle years into the mature writings. ${ }^{\prime} 22$ The idea that the best-adapted variety would come to dominate and would ultimately competitively eliminate other varieties in any given climate, as proposed by Hutton, Cowles Prichard, E.J. Scott and Henry Cheek, also clearly has an evident kinship with Darwin's mechanism of natural selection, even if most of these thinkers themselves considered species immutable. Desmond and Moore go so far as to claim that Darwin's idea of common descent, as opposed to the parallel lineages of many earlier evolutionary thinkers, can be traced directly straight back to the monogenist theories of race discussed in 1820s Edinburgh. ${ }^{83}$ Indeed, while working on what was to become the Origin of Species, Darwin himself wrote 'How like my Book all this will be' in the margin of Prichard's Researches into the Physical History of Mankind. ${ }^{84}$ 
Cheek, a contemporary of Darwin at Edinburgh and fellow member of both the RMS and Plinian Natural History Society, even went so far as to question the immutability of species and suggest that new species could arise from pre-existing ones. ${ }^{85}$ Cheek was a regular fixture at the Plinian Society, and he and Darwin were both present at no less than 16 of its meetings between December 1826 and April 1827. ${ }^{86}$ As attendance at these meetings could be as low as 12 members at this time, it is highly unlikely they were not acquainted. Like Cheek, Darwin was a member of the RMS; Cheek joined on 3 November 1826, while Darwin became a member on the 17th of the same month. ${ }^{87}$ It strains credibility to believe that he passed through this ferment of speculation on the very issues that were to occupy him for most of his later life in a state of blind indifference. Although many decades later Darwin was to write that his experiences at Edinburgh had no discernible influence on the development of his evolutionary thinking, a close examination of the ideas discussed in the student circles in which Darwin moved in 1820s Edinburgh make such claims seem decidedly disingenuous. ${ }^{88}$

School of History, University of St Andrews, St Katharine's Lodge, The Scores, St Andrews, Fife KY16 9BA, UK.

I would like to thank John Henry, Sarah Frank, Aileen Fyfe, Clare Button and Catherine Laing for taking the time to read and comment on a draft version of this paper. Thanks are also due to the British Journal for the History of Science's two reviewers for their extremely helpful and constructive comments and suggestions for improvements. Any remaining faults are, of course, my responsibility alone. 
${ }^{1}$ Adrian Desmond and James Moore, Darwin's Sacred Cause: Race, Slavery and the Quest for Human Origins, London: Penguin, 2009, p. xvi.

${ }^{2}$ Desmond and Moore, op. cit. (1), p.27.

${ }^{3}$ Nicholas Hudson, 'From 'nation' to 'race': The origin of racial classification in eighteenth-century thought', Eighteenth-Century Studies (1996) 29: 247-264.

${ }^{4}$ Thierry Hoquet, 'Biologization of race and racialization of the human', in Nicolas Bancel, Thomas David and Dominic Thomas (eds.), The Invention of Race: Scientific and Popular Representations, New York, NY: Routledge, 2014, p. 17.

${ }^{5}$ Mark Harrison, Climates and Constitutions: Health, Race, Environment and British Imperialism in India 16001850 (New Delhi: Oxford University Press, 1999), pp. 11-18.

${ }^{6}$ Kenan Malik, The Meaning of Race: Race, History and Culture in Western Society, Basingstoke: Macmillan, 1996, pp. 7-8.

${ }^{7}$ Nicolaas Rupke, 'Scientific racism and Huxley's rule', in Nicolaas Rupke and Gerhard Lauer (eds.), Johann Friedrich Blumenbach: Race and Natural History, 1750-1850, London: Routledge, 2019, p.235.

${ }^{8}$ Nancy Stepan, The Idea of Race in Science: Great Britain, 1800-1960, London: Macmillan. 1982, p. xv.

${ }^{9}$ Silvia Sebastiani, The Scottish Enlightenment: Race, Gender, and the Limits of Progress, New York: Palgrave Macmillan, 2013.

${ }^{10}$ The last of these, the author of the 'Inaugural disputation on the varieties of man', should not be confused with his namesake, John Hunter the famous London surgeon who was born in 1728.

${ }^{11}$ Patrick Brantlinger, Dark Vanishings: Discourse on the Extinction of Primitive Races, 1800-1930, Ithaca, NY: Cornell University Press, 2003, p. 13.

${ }^{12}$ See for example, James A. Secord, 'Edinburgh Lamarckians: Robert Jameson and Robert E. Grant', Journal of the History of Biology (1991) 24, pp. 1-18; Desmond, Adrian, The Politics of Evolution: Morphology, 
Medicine and Reform in Radical London, Chicago: University of Chicago Press, 1989; Jonathan Hodge, 'On

Darwin's science and its contexts', Endeavour (2014) 38, pp. 169-178; and Pietro Corsi, 'Jean-Baptiste

Lamarck, 'From Myth to History', in Snait B. Gissis, and Eva Jablonka (eds.), Transformations of

Lamarckism: From Subtle Fluids to Molecular Biology, Cambridge, MA: MIT Press, 2011, pp. 9-18.

${ }^{13}$ Stepan, op. cit. (8), p. xiii.

${ }^{14}$ Ludmilla Jordanova, 'Earth science and environmental medicine: the synthesis of the late

Enlightenment', in Ludmilla Jordanova and Roy Porter (eds.), Images of the Earth: Essays in the History of

Environmental Science, Chalfont St. Giles: British Society for the History of Science, 1997, p. 130.

${ }^{15}$ Hoquet, op. cit. (4), p. 21.

${ }^{16}$ The classic work on the subject is Arthur O. Lovejoy, The Great Chain of Being, Cambridge, MA, 1964.

See also William F. Bynum's important paper 'The great chain of being after forty years: An appraisal', History of Science (1975) 13, pp. 1-28.

${ }^{17}$ John Walker, Lectures on natural history, taken down by David Pollock (1797), 10vols., Edinburgh University Library. Gen.703-12D, vol. 3, f. 135.

${ }^{18}$ John Walker, Notes on Professor J. Walker's lectures on natural history (1791), Edinburgh University Library, Dc.10.33, f. 45.

${ }^{19}$ John Walker, Lectures on natural history (1790), 6 vols., Edinburgh University Library, Dc.2.25-28, vol. 4, f. 164.

${ }^{20}$ Walker, op. cit. (19), vol. 4, f. 166.

${ }^{21}$ Walker, op. cit. (17), vol. 9, ff. 135-6.

${ }^{22}$ William Smellie, The Philosophy of Nature, 2 vols., Edinburgh: Heirs of Charles Elliot, 1790, vol. 1, p.306.

${ }^{23}$ George Leclerc, Comte de Buffon, Histoire Naturelle, Générale et Particulière, avec la Descriptions du Cabinet du Roy, Paris: Imprimerie Royale, 1755, vol. 5, p. 194. 
${ }^{24}$ Alexander Monro, Secundus, Professor Monro's lectures (1786), Edinburgh University Library, Dc.10.13, f. 19.

${ }^{25}$ Buffon, op. cit. (23), vol. 1, p.38.

${ }^{26}$ Joseph Reade, 'What are principally the Causes of Variety in the Human Species (Read 24 October 1800)', Dissertations of the Royal Medical Society (1800) 43, Library of the Royal Medical Society of Edinburgh, pp. 99-114, p. 110.

${ }_{27}$ Plinian Natural History Society, Minutes of the Plinian Society, 1826-1841, 2 vols. Centre for Research Collections, Edinburgh University Library, Dc.2.53, vol. 1, p. 81. Browne went on to be a pioneering superintendent of Montrose Lunatic Asylum; see Andrew Scull, The Asylum as Utopia: W.A.F. Browne and the Mid-Nineteenth Century Consolidation of Psychiatry, London: Routledge, 1991.

${ }^{28}$ James Gray, History of the Royal Medical Society, 1737-1937, Edinburgh: Edinburgh University Press, 1952, p. 73.

${ }^{29}$ Nicholas C. Pitta, 'What is the influence of climate on the human species? And what are the varieties of men which result from it?, Dissertations of the Royal Medical Society (1811-12) 66, pp. 283-307, Library of the Royal Medical Society of Edinburgh) and Nicholas C. Pitta, ‘What is the influence of the climate on the human species and what are the varieties of man that result from it?', Royal Physical Society Dissertations (c. 1812) 31, pp. 190-210, Edinburgh University Library, Da.67 Phys.

${ }^{30}$ Nicholas C. Pitta, Influence of Climate on the Human Species; and on the Varieties of Men Resulting from It, London: Longman, Hurst, Rees, Orme and Brown, 1812.

${ }^{31}$ John Taylor, 'Are all men originally descended from the same stock?', Royal Physical Society Dissertations (1804-6) 24, pp. 464-71, Edinburgh University Library, Da.67 Phys, p.471. 
${ }^{32}$ See Colin Kidd, The Forging of Races : Race and Scripture in the Protestant Atlantic World, 1600-2000, Cambridge: Cambridge University Press, 2006 and David N. Livingstone, Adam's Ancestors: Race, Religion and the Politics of Human Origins, Baltimore, MA: John Hopkins University Press, 2008.

${ }^{33}$ William Webb, 'Are the diversities among mankind the effect of physical \& moral causes?', Dissertations of the Royal Medical Society (1794-95) 32, pp. 134-67, Library of the Royal Medical Society of Edinburgh), p. 167.

${ }^{34} \mathrm{E}$. Holme, 'To the operation of what causes are we to ascribe the variety of complexion in the human species?', Dissertations of the Royal Medical Society (1792-94), 29, pp. 366-81, Library of the Royal Medical Society of Edinburgh, p. 368.

${ }^{35}$ Hudson, op. cit (3), p. 253.

${ }^{36}$ Buffon, op. cit. (23), vol. 3 (1749), p.530

${ }^{37}$ Buffon, op. cit. (23), vol. 3 (1749), p.483.

${ }^{38}$ Samuel Stanhope Smith, An Essay on the Causes of the Variety of Complexion and Figure in the Human Species, Edinburgh: C. Elliot, 1788, p. 72.

${ }^{39}$ John Hunter, 'Inaugural disputation on the varieties of man' (1775), in Anthropological Treatises of Johann Friedrich Blumenbach and the Inaugural Dissertation of John Hunter, M.D. on the Varieties of Man (tr. Thomas Bendshye), London, 1865, p. 386.

${ }^{40}$ This is what Mark Harrison has described as a 'weak tranmutationist argument', with the inheritance of acquired characteristics leading to adaptive change within strict limits. See Harrison, op. cit. (5), p.104.

${ }^{41}$ For a useful discussion of the concept of degeneration in European discourses on race, see ClaudeOlivier Doron, 'Races et dégénérescence. L'émergence des savoirs sur l’homme anormal', PhD thesis, Histoire, Philosophie et Sociologie des sciences, Université Paris-Diderot - Paris VII, 2011 <tel-00876157>, pp. 137-211. 
${ }^{42}$ Buffon, op. cit. (23), vol. 14 (1766), p.311.

${ }^{43}$ Johann Friedrich Blumenbach, On the natural variety of mankind', 3rd edn (1795), in The Anthropological Treatises of Johann Friedrich Blumenbach and the Inaugural Dissertation of John Hunter, M.D. on the Varieties of Man (tr. Thomas Bendshye), London: Longman, Green, Longman, Roberts \& Green, 1865, p. 264.

${ }^{44}$ Blumenbach, op. cit. (43), p. 188.

45 Thomas Junker, 'Blumenbach's theory of human races and the natural unity of humankind,' in Rupke and Lauer, op. cit. (7), pp. 96-112, p. 104.

${ }^{46}$ For a more detailed discussion of Camper's views, see Miriam Claude Meijer, Race and Aesthetics in the Anthropology of Petrus Camper (1722-1789), Amsterdam: Rodopi, 1999, and the twelve essays in Klaas van Berkel and Bart Ramakers (eds.), Petrus Camper in Context: Science, the Arts and Society in the EighteenthCentury Dutch Republic, Hilversum: Verloren, 2015.

${ }^{47}$ John Bradley, 'Whence the varieties of the human species?', Dissertations of the Royal Medical Society (1791-92), 27, pp. 95-105, Library of the Royal Medical Society of Edinburgh, p. 98.

${ }^{48}$ W.F. Neville, 'What are the principle causes of the diversity of Colour in the human species?', Royal Physical Society Dissertations, no date, 29, pp. 118-29, Edinburgh University Library, Da.67 Phys, p. 471. ${ }^{49}$ J.C. Prichard, 'Of the varieties of the human race,' Dissertations of the Royal Medical Society (1807-8), 58, pp. 87-133, Library of the Royal Medical Society of Edinburgh, p. 133.

${ }^{50}$ Holme, op. cit. (34), p. 379.

${ }^{51}$ John Fitzgerald, 'To what causes are we to attribute the difference of colour in the human race?', Royal Physical Society Dissertations (1798-1800), 19, pp. 4-13, Edinburgh University Library, Da.67 Phys, p. 9. 52 Webb, op. cit. (33), p. 136.

${ }^{53}$ [William] Scully, 'Question on the causes of variety among mankind', Royal Physical Society Dissertations (1802-4), 22, pp. 79-85, Edinburgh University Library, Da.67 Phys, p. 80. 
${ }^{54}$ Samuel Cramer, 'What influence has climate on the human constitution?', Royal Physical Society

Dissertations (1798-1800), 19, pp. 475-92, Edinburgh University Library, Da.67 Phys), p. 489.

${ }^{55}$ Robert Jameson, Notes on zoology lectures (notes taken by an anonymous student), 2 vols. (no date),

Centre for Research Collection, Edinburgh University Library Dc.2.34, vol. 2, f.237.

${ }^{56}$ Blumenbach's system of classification was also to strongly influence medical understandings of racial difference in the colonies; see, for example, David Arnold, 'Race, place and bodily difference in early nineteenth-century India', Historical Research, 2004, 77: 254-273, p. 258.The extent to which racial theory conditioned colonial attitudes is also explored in Shruti Kapila, 'Race Matters: Orientalism and Religion, India and Beyond c.1770-1880', Modern Asian Studies, 2007, 41: 471-513.

${ }^{57}$ Robert Jameson, Notes on natural history lectures (1822-23) (taken by George Gordon), Elgin Museum L.1987.5.3 (28/5), f. 1.

${ }^{58}$ Dugald Stewart, 'Notes from a course of lectures on moral philosophy delivered by Dugald Stewart' (taken by John Borthwick) (1806-7), Centre for Research Collections, Edinburgh University Library, Gen.843, f. 367. For Camper's use of this example, see Meijer, op. cit. (46), p.82.

${ }^{59}$ For an account of this period of Knox's life, see A.W. Bates, The Anatomy of Robert Knox: Murder, Mad Science and Medical Regulation in Nineteenth-Century Edinburgh (Brighton: Sussex Academic Press, 2010), pp.33-41.

${ }^{60}$ Robert Knox, Inquiry into the origin and characteristic differences of the native races inhabiting the extra-tropical part of southern Africa, Memoirs of the Wernerian Society, 1824, 5: 206-19.

${ }^{61}$ Knox, 'op. cit. (60),' p.210.

${ }^{62}$ Evelleen Richards, 'The 'Moral Anatomy' of Robert Knox: The interplay between biological and social thought in Victorian scientific naturalism,' Journal of the History of Biology, 1989, 22: 373-436. 
${ }^{63}$ John Bradley, 'Whence the varieties of the human species?,' Dissertations of the Royal Medical Society, 1791-92, 27: 95-105 (Library of the Royal Medical Society of Edinburgh), on p.97.

${ }^{64}$ Fitzgerald, op. cit. (51), p.6.

${ }^{65}$ Fitzgerald, op. cit. (51), p.6.

${ }^{66}$ John Taylor, 'Are all men originally descended from the same stock?', Royal Physical Society

Dissertations, 1806-6, 24: 464-71 (Edinburgh University Library, Da.67 Phys), on p.464.

${ }^{67}$ Meijer, op. cit. (46), pp. 47-9.

${ }^{68}$ Robert Jameson, Student's notes of Jameson's lectures on natural history delivered in Edinburgh

University, 1816-17, Edinburgh University Library, Dc.10.32, f. 1.

${ }^{69}$ John Hunter, op. cit. (39), p. 362.

70 Smith, op. cit. (38), pp. 21-2.

${ }^{71}$ James Hutton, unpublished Treatise on Agriculture, 2 vols., National Library of Scotland, MS.23165-6, vol. 2, f. vi.

${ }^{72}$ Hutton, op. cit. (71), vol.2, f. vii.

${ }^{73}$ James Cowles Prichard, Researches into the Physical History of Man, 2nd edn., 2 vols,, London: John and Arthur Arch, 1826, vol. 2, pp. 574-5.

${ }^{74}$ Prichard, op. cit. (73), vol. 2, p. 581-2.

${ }^{75}$ H.F. Augstein, James Cowles Prichard's Anthropology: Remaking the Science of Man in Early Nineteenth Century Britain, Amsterdam: Rodopi, 1999, pp. 108-9.

${ }^{76}$ E.J. Scott, 'What are the causes of the diversities of the human species?', Dissertations of the Royal Medical Society (1833), 95, pp. 317-57, Library of the Royal Medical Society of Edinburgh, p. 357. ${ }_{77}$ Scott, op. cit. (76), p. 357. 
${ }^{78}$ Henry H. Cheek, 'On the varieties of the human race (Read 29 January 1830)', Dissertations of the Royal Medical Society (1829-30) 91, pp. 286-307, Library of the Royal Medical Society of Edinburgh, pp. $306-7$.

${ }^{79}$ Cheek, op. cit. (78), p. 306.

${ }^{80}$ Cheek, op. cit. (78), p. 302.

${ }^{81}$ Dov Ospovat, The Development of Darwin's Theory: Natural History, Natural Theology and Natural Selection 1838-1859, Cambridge: Cambridge Univ. Press, 1981, pp. 70-3.

82 Phillip R. Sloan, 'Darwin, Vital Matter, and the Transformism of Species', Journal of the History of Biology (1986) 19, pp. 369-445, p. 372.

${ }^{83}$ Desmond and Moore, op. cit. (1), p. 112.

${ }^{84}$ Mario A. De Gregorio and N. W. Gill (eds.), Charles Darwin's Marginalia, vol. 1, New York, NY: Garland, 1990, p. 683.

${ }^{85}$ Bill Jenkins, "'Henry H. Cheek and transformism: New light on Darwin's Edinburgh background', Notes and Records: The Royal Society Journal of the History of Science (2015) 69, pp. 155-71.

${ }^{86}$ Plinian Natural History Society, Minutes of the Plinian Society, 2 vols., Edinburgh University Library, Dc.2.53, vol. 1 .

${ }^{87}$ Royal Medical Society, List of Members, The Royal Medical Society of Edinburgh, Edinburgh: Royal Medical Society, 1906, p. 44.

${ }^{88}$ Charles Darwin, 'Recollections of the development of my mind and character', in Charles Darwin, Autobiographies, London: Penguin, 2002, p. 24. 